\title{
The Effects of Directors' Exploratory, Transformative and Exploitative Learning on Boards' Strategic Involvement: An Absorptive Capacity Perspective
}

\begin{abstract}
While directors' knowledge represents a crucial resource for strategizing on boards, little is known how knowledge of individual directors becomes deployed behind the doors of the boardroom. Drawing on the concept of absorptive capacity, we develop a model that explores how directors' explorative, transformative and exploitative learning affects boards' strategic involvement. Using large-scale survey data, our findings indicate that learning helps to explain how directors' knowledge leads to higher levels of strategic involvement. Moreover, we find that learning processes mutually reinforce each other and have complementary effects on boards' strategic involvement. Our study contributes to the board and absorptive capacity literatures by demonstrating that learning processes are interconnected with each other and represent an intermediate way to put directors' knowledge into effective use.
\end{abstract}




\section{Introduction}

Boards' strategic involvement refers to the extent to which boards engage in shaping the content, process, and conduct of strategy (McNulty and Pettigrew, 1999), and represents an important determinant of directors' contributions to corporate value creation. Strategic involvement has been shown to influence firms' decision behaviors (Nielsen and Huse, 2010), including for example organizational ambidexterity (Heyden et al., 2015) and innovation (Torchia, Calabrò and Huse, 2011). Whereas early studies were skeptical concerning directors' contributions to strategy and there was a dearth of knowledge regarding its antecedents (Pugliese et al., 2009), more recent literature suggests that strategic decisions greatly benefit from directors' industry-specific knowledge (Kor and Sundaramurthy, 2009), experience from serving as a top executive (Khanna, Jones and Boivie, 2014) and specialized task-specific expertise (McDonald, Westphal and Graebner, 2008).

Yet the processes by which boards make use of individual directors' knowledge have not yet been completely understood. Process losses (Forbes and Milliken, 1999) and cognitive constraints (Rindova, 1999) often prevent directors from applying their knowledge in a strategic decision-making context. Forbes and Milliken (1999) made an important distinction between the presence and use of knowledge, arguing that the latter requires high degrees of mutual respect and collective learning among directors. While there is some empirical support for this suggestion (Minichilli et al., 2012; Zattoni, Gnan and Huse, 2015), and research demonstrates that directors who actively participate in strategic decision-making tend to learn behavioral procedures more deeply (Westphal and Zajac, 2013), not much theoretical reasoning exists on how learning enables boards to explore and transform their available knowledge and apply it to strategic tasks. Notwithstanding the few studies that adopt a learning perspective in this context (McDonald, Westphal and Graebner, 2008; Tuschke, Sanders and Hernandez, 2014; Westphal, Seidel and Stewart, 2001), we have a limited understanding 
about how learning processes relate to each other and affect board's strategic decision-making in concert.

In this study, we ask the following question: "How does directors' exploratory, transformative and exploitative learning affect boards' strategic involvement?". Theoretically, we draw on the concept of absorptive capacity to explain how boards obtain, share, and apply individual directors' knowledge to strategic matters. Absorptive capacity refers to the ability to explore, transform, and exploit new information and knowledge (Cohen and Levinthal, 1990; Zahra and George, 2002) and has been shown to be a valuable construct to explain how firms make use of their resources for strategic applications (Ebersberger and Herstad, 2011; Tortoriello, 2015). We argue that absorptive capacity and its focus on knowledge gathering, sharing, and exploiting from learning shares parallels with utilizing directors' knowledge (Zahra, Filatotchev and Wright, 2009), and allows for a finer-grained explanation of how knowledge leads to strategic involvement. Additionally, in line with the absorptive capacity literature (Todorova and Durisin, 2007; Zahra and George, 2002), we suggest that multiple learning processes are mutually reinforcing (Lane, Koka and Pathak, 2006), and the joint adoption of all learning processes may be greater than the sum of benefits obtained from the isolated adoption of single ones (Milgrom and Roberts, 1995).

We test our arguments using large-scale survey data from Norwegian boards. Norwegian boards tend to have an active role in shaping the content, process, and conduct of strategy (Zattoni, Gnan and Huse, 2015) that can foster discussions to absorb the knowledge of individual directors (Cadiz, Sawyer and Griffith, 2009). Our study makes two important contributions. First, by introducing the concept of absorptive capacity into research on boards, we provide theoretical insights into how individual directors' knowledge leads to higher levels of boards' strategic involvement. The relatively sparse prior research on learning in boards has focused on single sources of learning such as interlocks (Tuschke, Sanders and Hernandez, 
2014), or participation in strategic decision-making processes (Westphal and Zajac, 2013), but rarely considered that learning may be better understood as an ongoing process of interrelated activities (Argote and Miron-Spektor, 2011). In support of this reasoning, our findings indicate that exploratory, transformative, and exploitative learning mediate the relationship between directors' knowledge and boards' strategic involvement. Second, we contribute to the absorptive capacity literature (Lane, Koka and Pathak, 2006; Zahra and George, 2002) by focusing on the effects of learning processes at a group level. While firm-level antecedents and consequences of absorptive capacity received much attention (Flatten, Greve and Brettel, 2011), Volberda, Foss and Lyles (2010) emphasize that a deeper understanding of absorptive capacity requires reference to upper-echelons such as boards of directors. Because scholars tend to treat absorptive capacity as a static construct (Lane, Koka and Pathak, 2006) and thereby miss out on its richness and multidimensionality (Volberda, Foss and Lyles, 2010), we adopt a process view of absorptive capacity and develop a model that explains how knowledge is gathered, shared, and exploited at a group level (Martinkenaite and Breunig, 2016).

\section{Governance and Boards in the Norwegian Institutional Setting}

Our theoretical framework and subsequent hypotheses are developed and tested using largescale survey data from Norway. Norway is a small country in Northern Europe and can be classified as a civil law country with a two-tier corporate governance system. The Norwegian Code of Practice for Corporate Governance shares many similarities with codes in other European countries, including recommendations concerning board structures as well as the division of responsibilities among boards, shareholders and management. Specifically, the Norwegian corporate governance system is characterized by a tiered board structure, concentrated ownership, and a strong regulatory regime including mandatory employee representation on 
boards (Rasmussen and Huse, 2011; Sinani et al., 2008). We describe each of these aspects in turn.

Norwegian corporate law differentiates between executive managers (most often the CEO) and supervisory boards. CEO duality (i.e., the practice of a single individual serving as both CEO and board chair) is prohibited in Norway, yet CEOs typically participate in board meetings (Grosvold, Brammer and Rayton, 2007). Norwegian boards have comparatively high discretion concerning strategic decision-making and are expected to "lead the company's strategic planning, and make decisions that form the basis for the executive management" (Norwegian Code of Practice for Corporate Governance). Research accordingly describes boards as active in strategic decision-making (Machold et al., 2011) and particularly influential in shaping firm performance (Lohe and Calabrò, 2017; Zattoni, Gnan and Huse, 2015).

A second characteristic of Norwegian corporate governance is the prevalence of ownership concentration. Like in most other European countries, ownership in Norway is traditionally under the influence of a controlling shareholder, with families and the state playing the most important roles (Mishra, Randoy and Jenssen, 2001). Control is typically enacted through director selection as well as pyramid and dual class shareholding (Sinani et al., 2008). Boards of directors are elected by the general meeting of shareholders or, where applicable, by a corporate assembly. Yet Norway has opened up considerably to foreign and institutional investors since the 1990s, with governance principles becoming more accessible to an international audience (Rasmussen and Huse, 2011).

Finally, Norway is known for its strong regulatory regime, particularly regarding boardlevel employee and gender representation (Grosvold, Brammer and Rayton, 2007). Depending on the size of the firm, Norwegian boards consist of shareholder and employee representatives. In firms with more than 50 employees, one third of board seats can be elected by firm employees. Such employee representation adds firm-specific knowledge and strengthens crea- 
tive discussion (Huse, Nielsen and Hagen, 2009). In addition, there has been high institutional pressure for equal gender representation since the mid-1990s. Gender diversity adds knowledge to boards' strategic discussions (Terjesen, Sealy and Singh, 2009), supports innovation (Torchia, Calabrò and Huse, 2011) and contributes to firm performance (Post and Byron, 2015).

In sum, the Norwegian corporate governance system presents important similarities and differences with other European countries. From prior research we can conclude that Norwegian boards are consistently involved in strategic decision-making (Machold et al., 2011; Minichilli et al., 2012) and hence represent an appropriate setting to develop our framework and test our hypotheses.

\section{Theoretical Background and Literature Review}

\section{Reviewing the Directors' Knowledge-Boards' Strategic Involvement Relationship}

Directors' knowledge has emerged as a major construct within the board literature (Bankewitz, 2017; Khanna, Jones and Boivie, 2014; Minichilli et al., 2012), referring to "skills and experiences that individual directors bring to the decision-making process" (Johnson, Schnatterly and Hill, 2013: 240). There has been an intense debate regarding the characteristics of directors' knowledge and its relationship with boards' strategic involvement (Johnson, Schnatterly and Hill, 2013; Pugliese et al., 2009), and two broad conceptualizations can be identified: the demographic versus the behavioral approach. According to the demographic approach, directors bring a set of knowledge attributes to the board that they use to contribute to shaping the content, process, and conduct of strategy (Kor and Sundaramurthy, 2009; Sundaramurthy, Pukthuanthong and Kor, 2014). This view builds on the implicit assumption that demographic features are valid proxies for directors' unobservable skills (Hambrick and Mason, 1984), an assumption which is increasingly being questioned (Daily, 
Dalton and Cannella, 2003). The behavioral approach extends the demographic stream by arguing that the deployment of individual directors' knowledge requires a stronger reference to behavioral and cognitive dimensions (van Ees, Gabrielsson and Huse, 2009). In an early attempt to solve the puzzle between the demographic versus behavioral approach, Forbes and Milliken (1999) proposed that the concept "use of knowledge and skills" -the board's ability to "to tap the knowledge and skills available to it and then apply them to its tasks"-would mediate the relationship between directors' knowledge and boards' strategic involvement. However, evidence for this proposition is mixed, with studies finding positive (Machold et al., 2011; Minichilli et al., 2012; Zattoni, Gnan and Huse, 2015), non-linear (van Ees, van der Laan and Postma, 2008), and no effects (Zona, 2016).

Given this ambiguity, a number of scholars have called for a better theoretical account of how directors' knowledge is being explored, transformed and exploited for firms' strategic matters (Johnson, Schnatterly and Hill, 2013; Pugliese et al., 2009). Learning processes have been advanced as a possible explanation in this regard (van Ees, Gabrielsson and Huse, 2009; Westphal and Zajac, 2013) and prior research suggests that directors increase their strategic involvement through learning from fellow directors (Carpenter and Westphal, 2001), learning from affiliations with other firms (Tuschke, Sanders and Hernandez, 2014), and learning from their experience with prior strategic deployments (McDonald, Westphal and Graebner, 2008). What is hitherto missing is a theoretical framework for learning processes in boards and their role in activating directors' knowledge towards involvement in strategic board tasks.

\section{The Concept of Absorptive Capacity and Theoretical Framework of the Study}

The concept of absorptive capacity offers a theoretical perspective to further elaborate on the directors' knowledge-boards' strategic involvement relationship by arguing that learning is an essential process to put knowledge into effective use (Zahra, Filatotchev and Wright, 2009; 
Zahra and George, 2002). In their seminal work, Cohen and Levinthal (1990) defined absorptive capacity as a firm's ability to recognize the value of new external information, assimilate it, and apply it to commercial ends (p.128). This definition assumes that a firm's absorptive capacity is likely to develop cumulatively, is path dependent, and builds on a stock of existing knowledge of a firm's individuals (Volberda, Foss and Lyles, 2010).

Several authors have offered reconceptualizations and empirical extensions of the construct, although existing definitions and their conceptual components remain heterogeneous and unclear (Zahra and George, 2002). Additionally, many scholars treat the specific learning processes that constitute a firm's absorptive capacity as a "black box", and only scant attention is paid to its underlying elements (Todorova and Durisin, 2007). Lane, Koka and Pathak (2006) developed a process model of absorptive capacity that specifies three dimensions: (1) exploratory learning, which refers to recognizing and understanding firm-external knowledge; (2) transformative learning, which is conceptualized as the sharing and transformation of the assimilated knowledge, and (3) exploitative learning, which is related to the application of acquired knowledge for new knowledge creation. This is consistent with the original concept by Cohen and Levinthal (1990) who posit that distinct learning mechanisms, the structure of communication between the external environment and the firm, and an active network of relationships, can influence a firm's absorptive capacity (Volberda, Foss and Lyles, 2010).

To enhance their strategic involvement, we argue that boards need to develop and engage in all dimensions of absorptive capacity processes simultaneously (Zahra and George, 2002). Specifically, the ability to recognize and understand firm-external knowledge (i.e., exploratory learning) may enable the board to create an enlarged knowledge base for strategic decision-making. Yet this alone will not be sufficient in fostering strategic involvement, unless the knowledge base is also transformed and translated into new knowledge creation (Flatten, Greve and Brettel, 2011). Based on existing theoretical and empirical insights, we 
next develop hypotheses concerning the effects of all three learning processes to examine their overall effect on boards' strategic involvement (see Figure 1).

Insert Figure 1 about here

\section{Hypotheses Development}

The Direct Effect of Directors' Knowledge on Boards' Strategic Involvement

Consistent with the absorptive capacity literature (Gebauer, Worch and Truffer, 2012), Forbes and Milliken (1999) argued that directors' functional and firm-specific knowledge form the pool of available knowledge that the board has at its disposal. Functional knowledge refers to expertise in specific business areas (e.g., finance, strategy), and knowledge about the external environment (e.g., customers, competitors). Firm-specific knowledge refers to directors' understanding of the focal firm's operations and management issues. Following the absorptive capacity logic, the ability to explore, transform and exploit knowledge depends on a board's existing knowledge base (Cohen and Levinthal, 1990) that facilitates defining the locus of new knowledge search (Rosenkopf and Nerkar, 2001).

Prior research suggests that directors' knowledge enables access to and the processing of task-related information (Johnson, Schnatterly and Hill, 2013), fosters directors' awareness of emerging strategic issues (Judge and Dobbins, 1995) and provides a set of abstract problem-solving heuristics that can be applied to strategic topics (McDonald, Westphal and Graebner, 2008). Additionally, firm-specific knowledge contributes to a deep-level understanding of inner-firm processes, resulting in the sharing of a common language with firm executives (Kor and Sundaramurthy, 2009; Sundaramurthy, Pukthuanthong and Kor, 2014). Because such a mutual understanding fosters trustworthiness, executives tend to value input from boards in strategic decision-making contexts to a greater extent (Westphal, 1999). 
These arguments are supported by empirical investigations. For example, directors' functional knowledge enables boards to be better equipped to contribute to firm performance through higher quality of discussions (Vandenbroucke, Knockaert and Ucbasaran, 2016), and reduces information ambiguity in strategic decision-making (Judge et al., 2015). Additionally, firm-specific knowledge contributes to tacit knowledge gains about the firm (De Maere, Jorissen and Uhlaner, 2014), and leads boards to more accurately interpret information provided by management (Kor and Sundaramurthy, 2009). In sum, insights from this information processing perspective lend support to the proposition that functional and firm-specific knowledge are a necessary precondition for boards' strategic involvement. We therefore hypothesize:

Hypothesis 1: Directors' knowledge is positively related to boards' strategic involvement.

\section{The Mediating Effect of Exploratory Learning}

While knowledge is considered an indispensable factor for boards' strategic involvement, simple aggregations of directors' knowledge fall short of explaining how boards employ directors' individual knowledge at a group-level (Johnson, Schnatterly and Hill, 2013). In the process view of absorptive capacity, a stock of knowledge alone does not ensure successful knowledge application, and firms must establish scanning mechanisms to recognize and understand their external environment (Cohen and Levinthal, 1990). In this context, exploratory learning refers to recognizing and understanding external knowledge (Lane, Koka and Patkak, 2006) and "directs attention to the intensity, speed, and effort to gather knowledge" (Todorova and Durisin, 2007: 777). Khanna, Gulati and Nohria (1998) proposed that a detailed understanding of all relevant problem-solving techniques facilitates knowledge application, and exploration may help to sustain a competitive advantage in dealing with customers 
and competitors (Zahra and George, 2002). Hence, exploratory learning should help to explain how directors' knowledge is deployed for strategic involvement.

There is some evidence to support this theoretical reasoning. First, intensive preparations of board meetings have been shown to facilitate critical discussions in the board and increase independence from top executives (Huse, 2007: 221), which in turn affects the propensity to be involved in strategic tasks (Minichilli et al., 2012). Moreover, the availability and dedication of time to prepare meetings is crucial for effective decision-making (Payne, Benson and Finegold, 2009). Second, the speed of knowledge gathering is a key feature for boards' strategic involvement, especially in times of crises (Pirson and Turnbull, 2011). One pivotal characteristic in this matter is the timing and timeliness of information provision. In the absence of timely information, boards will not have the most accurate or relevant information at hand to be involved in strategic decisions. Thus, the timely availability of information is likely to allow for a more comprehensive recognition and understanding of external knowledge (Zhang, 2010). Third, efforts to gather knowledge are likely to depend on information flows within and across boards. Westphal, Seidel and Stewart (2001) suggest that board interlocks facilitate information flows from outside the firm and support learning from external sources. Moreover, information exchange between CEOs and boards (Zahra and Pearce, 1989), and active information search from non-managerial internal and external sources benefit strategic decision-making (Pirson and Turnbull, 2011). Active information search is further related to information verification, for example through triangulating management reports and proposals (Zhang, 2010).

Accordingly, we expect that intensive preparation of board meetings, the speed of information flows, and information gathering from internal and external sources characterize exploratory learning in the board. This process is likely to affect the deployment of directors' knowledge, and leads to a higher involvement in firms' strategic decision-making. 
Hypothesis 2a: Exploratory learning in the board mediates the positive relationship between the directors' knowledge and boards' strategic involvement. 


\section{The Mediating Effect of Transformative Learning}

Transformative learning links exploratory and exploitative learning processes and refers to maintaining and developing knowledge over time (Lane, Koka and Pathak, 2006). Firms must be enabled to combine, share and store their pre-existing knowledge as well as adapt it to emerging opportunities (Flatten, Greve and Brettel, 2011). This includes an active management of knowledge retention to keep the firm "up to date" with the external environment (Lane, Koka and Pathak, 2006) and reactivate knowledge when needed (Argote, McEvily and Reagans, 2003). In turn, scholars suggest that transformative learning enables firms to develop new perceptual schema in dealing with strategic decisions (Zahra and George, 2002) and become more capable in changing their cognitive repertoire to absorb new knowledge (Todorova and Durisin, 2007).

To maintain and develop knowledge over time, communication among directors is pivotal as it creates the necessary social conditions for learning to occur (Ellison and Fudenberg, 1995). Prior research indicates that communication quality and frequency are linked to effective decision-making in boards (Farquhar, 2011). Communication not only eases mutual understanding among directors, but also ensures the credibility of all relevant and useful information (Massey and Dawes, 2007). Accordingly, the deployment of directors' knowledge is likely to depend on how effective communication supports the maintenance and development of knowledge over time. Additionally, transformative learning is likely to depend on the quality of interactions during board meetings. Board meetings play a crucial role in knowledge transformation (Parker, 2007), because they provide a formal structuring element to make use of directors' existing knowledge. For example, lengthy presentations of known information during board meetings lead to a reduction in time for the discussion of critical decision-making aspects (Machold and Farquhar, 2013), indicating that knowledge transformation is unlikely to occur in such circumstances. Moreover, formalized meeting agendas 
detract attention away from openly debating strategy towards routinely reviewing proposals (Inglis and Weaver, 2000). A final critical aspect of transformative learning is concerned with the combination of directors' knowledge. Judge et al. (2015) suggest that directors' knowledge breadth and depth enables a more comprehensive assessment of strategic options and reduces decision-making information asymmetries. Similarly, balancing knowledge of directors and top executives is likely to improve a firm's ability to deal with new demands (Sundaramurthy, Pukthuanthong and Kor, 2014), indicating that mutual familiarity with each other's' knowledge enables directors to maintain and develop their knowledge and translate it into higher degrees of strategic involvement.

In sum, transformative learning is likely to ease the deployment of directors' knowledge and increase boards' strategic involvement by fostering communication among directors, ensuring activity in board meetings and combining directors' knowledge.

Hypothesis 2b: Transformative learning in the board mediates the positive relationship between directors' knowledge and boards' strategic involvement.

\section{The Mediating Effect of Exploitative Learning}

Exploitative learning refers to the application of acquired knowledge for new knowledge creation (Lane, Koka and Pathak, 2006) and commercial purposes (Cohen and Levinthal, 1990). Recent conceptualizations suggest that knowledge transformation and exploitation are interlinked through feedback loops (Volberda, Foss and Lyles, 2010) and form a reinforcing virtuous circle until knowledge becomes exploited (Todorova and Durisin, 2007). Because exploitative learning assists developing new perceptual schema (Jansen, Van den Bosch and Volberda, 2005), a systematic exploitation is likely to enable firms to incorporate explored and transformed knowledge into their operations (Lane and Lubatkin, 1998), but also to create 
new systems, processes and competencies that can be used to more effectively match a firm with its markets and customers (Zahra and George, 2002).

There is evidence to indicate that the exploitation of directors' knowledge affects the outcome of strategic decisions (Tuschke, Sanders and Hernandez, 2014). McDonald, Westphal and Graebner (2008) for example show that knowledge eases the assessment of large quantities of information and identification of solutions to strategic initiatives. Likewise, directors' knowledge can be configured to improve efficiencies in strategic decisions-making by reducing and/or broadening R\&D spending (Dalziel, Gentry and Bowerman, 2011) or choosing between exploration versus exploitation strategies (Heyden et al., 2015). Additionally, it has been shown that knowledge exploitation affects boards' initialization and evaluation of strategic decisions. Zattoni, Gnan and Huse (2015) indicate that the exploitation of directors' knowledge strengthens boards' strategic involvement and results in higher firm performance.

Combining these arguments, we suggest that boards' strategic involvement increases if exploitative learning enables directors to apply their knowledge for strategic decision-making.

Hypothesis 2c: Exploitative learning in the board mediates the positive relationship between directors' knowledge and boards' strategic involvement.

The Mediating Effect of Complementarities between Learning Processes. So far, we theorized that each learning process individually facilitates the deployment of directors' knowledge for boards' strategic involvement. Yet learning is unlikely to play out in such an atomized and unconnected fashion, because processes in boards are intertwined (Huse, 2007) and range on a continuum between activity and passivity (Machold and Farquhar, 2013).

The absorptive capacity perspective suggests that exploratory, transformative and exploitative learning may have complementary effects (Zahra and George, 2002), because learn- 
ing tends to accumulate over time and depends on prior absorptive capacity processes (Cohen and Levinthal, 1990). Complementarities refer to firm-inherent 'fits' among certain practices, whereby the enforcement of one practice increases the marginal return of others (Milgrom and Roberts, 1995). While all three learning processes have distinct contributions for strategic decision-making (Jansen, Van den Bosch and Volberda, 2005), research conceptualizes learning as interdependent and mutually supportive (Argote and Miron-Spektor, 2011). For example, a firm with strong exploratory learning may develop more effective strategies for high levels of exploitative and transformative learning (Zahra and George, 2002). In contrast, a firm that fails to deeply engage in knowledge exploration and transformation is unlikely to have the necessary ability for an effective exploitation (Katila and Ahuja, 2002).

Accordingly, boards' strategic involvement is likely to increase if directors are highly engaged in all three learning processes. By spending sufficient time to prepare and seek out information (exploratory learning), discussing ideas (transformative learning), and applying it to strategic decision-making (exploitative learning), we argue that boards' strategic involvement is likely to increase. We propose that complementary effects are more likely than substitutional effects whereby one learning process may adjust for weaknesses in another one (Cohen and Levinthal, 1990). Boards may well engage in extensive preparation of board meetings and discussions about strategic options, but if they lack the ability to apply and exploit the output of these learning processes, their involvement in strategy is less likely to be of importance.

Thus, the three dimensions of absorptive capacity are likely to complement each other, and boards' strategic involvement thus benefits from complementarities between exploratory, transformative, and exploitative learning. 
Hypothesis 3: Complementarities between exploratory learning, transformative learning, and exploitative learning mediate the positive relationship between directors' knowledge and boards' strategic involvement. 


\section{Methods}

\section{Sample}

To test our hypotheses we follow a theory-driven deductive research design and use data collected through the first version of the Value Creating Board survey instrument (Huse, 2009). This is an openly available, comprehensive instrument that has been used in several countries such as Italy, Belgium and the Netherlands (Minichilli et al., 2012; Voordeckers et al., 2014). For our purpose we decided to use data from Norway with responses from CEOs in the 2003 “innovation" survey (Huse, 2009). Our motivation to use this survey stems from the coverage of a broad variety of firms (35\% listed on the Oslo Stock Exchange, 33\% publicly-owned, and $25 \%$ foreign-owned) and the strong reliance on constructs used or suggested in prior research. The CEOs had been contacted via mail and sent two postal reminders as well as one followup telephone call to increase the sample size and response rate. Of the initial sample of 1730 CEOs, a total of 28 percent or 488 CEOs responded. Following prior research (Machold et al., 2011; Minichilli et al., 2012), we consider CEOs as the most informed actor to evaluate boards and provide a valid judgment about boards' strategic involvement (Zattoni, Gnan and Huse, 2015), especially in our context of Norwegian boards (Grosvold, Brammer and Rayton, 2007). To test for a self-attribution bias, we correlated the CEO's perception of boards' strategic involvement with two potential proxies of CEO power (Pugliese, Minichilli and Zattoni, 2014). We found a small correlation between boards' strategic involvement and CEO tenure $(\mathrm{r}=.132 ; \mathrm{p}<.05)$, and no correlation between boards' strategic involvement and CEO age ( $\mathrm{r}=-$ $.060 ; \mathrm{p}>.05)$. This implies that self-attribution bias does not systematically bias our results.

Several procedures were utilized to minimize a common method bias (Podsakoff et al., 2003). First, all survey items had been recommended and used in previous studies, and scales had been pre-tested through pilot studies and preliminary expert interviews to reduce item ambiguity (Huse, 2009). Second, an introductory letter guaranteed anonymity and confidenti- 
ality to reduce social desirability bias. Third, all variables had been kept separate from each other in the survey to avoid spill-over effects. Finally, the introductory letter stated that no 'right or wrong' answers existed and encouraged the respondents to be as candid as possible. We used Harman's one factor test to test for common method bias (Podsakoff et al., 2003). Exploratory factor analysis of all constructs exhibited more than one factor with eigenvalues higher than 1.0, suggesting that most variance accounts for more than one general factor. The partial correlation procedure that controls for the effects of method variance did not reveal any indication for the existence of common method bias (Lindell and Whitney, 2001).

\section{Variables and Measures}

Boards' Strategic Involvement. Boards' strategic involvement is a latent and multi-dimensional construct (Pugliese et al., 2009). We utilize a six item measure that has been used in other studies (Zattoni, Gnan and Huse, 2015) and confirmed in recent field work (Machold and Farquhar, 2013). Specifically, the CEO was asked to which degree the board provides advice on (1) general management issues (2) financial issues, (3) technical issues, (4) market issues, and to which degree the board (5) actively initiates strategy proposals and (6) makes decisions on long-term strategy. Cronbach's alpha is 0.85 .

Directors' Knowledge. We distinguish between "firm-specific knowledge" and "functional knowledge" to measure directors' knowledge (Forbes and Milliken, 1999). In line with other studies (Machold et al., 2011; Minichilli and Hansen, 2007), directors' knowledge was measured by asking the CEO to which extent board members have (1) knowledge of firms' main operations, (2) knowledge of firms' critical technology and key competence, (3) knowledge of firms' weak sides concerning products and services, (4) knowledge of the developments of the firm's technology, (5) knowledge of firms' health, security and environment, (6) 
knowledge of developments concerning firm's markets and customer's needs. Cronbach's alpha is 0.83 .

Mediating Variables. Due to the exploratory approach in applying the absorptive capacity concept in a group context, pre-validated scales were not available. We derived measures from the absorptive capacity literature (Cadiz, Sawyer and Griffith, 2009; Camisón and Forés, 2010; Flatten et al., 2011; Jansen, Van Den Bosch and Volberda, 2005; Szulanski, Cappetta and Jensen, 2004) and aligned these measures as closely as possible to the constructs of our study (Lane, Koka and Pathak, 2006). All measures show acceptable levels of construct reliability (see Table 3 in the results section).

We use a seven-item measure to assess exploratory learning. The first item covers how fast information circulates to exchange and develop new and unknown knowledge (Flatten et al., 2011). The second and third items assess whether directors are active in seeking and collecting information (Cadiz, Sawyer and Griffith, 2009). The fourth and fifth items cover the information flow from inside the firm and its employees (Volberda, Foss and Lyles, 2010), and the last two items measure exploratory learning from firm-external sources (Flatten et al., 2011; Jansen, Van Den Bosch and Volberda, 2005). To measure exploratory learning, the CEO was asked to which extent the board members (1) have a fast information flow between themselves, (2) explore information before meetings, (3) actively seek information in addition to management reports, (4) are familiar with employees' view on health, security and environment, (5) are familiar with employees' view on management-union collaborations, (6) are building networks, and (7) are lobbying and legitimating. Cronbach's alpha is 0.71.

The construct transformative learning covers the availability and utilization of knowledge (Flatten et al., 2011; Jansen, Van Den Bosch and Volberda, 2005) and directors' familiarity with knowledge distribution in the board (Cadiz, Sawyer and Griffith, 2009; 
Szulanski, Cappetta and Jensen, 2004). The CEO was asked if board members (1) are familiar with each other's competence, (2) have a good match of work and knowledge and skills, (3) fully use their knowledge and skill, (4) give sufficient priority to the board tasks, (5) are available if needed, and (6) are all active during their meetings. Cronbach's alpha is 0.85 .

Exploitative learning is measured using items related to the application of knowledge for innovative actions, without delving into innovation itself (Cadiz, Sawyer and Griffith, 2009; Camisón and Forés, 2010). Exploitative learning was assessed by asking the CEO if the firm is considered as (1) being the first firm to introduce new products to the market, (2) being the first firm to develop and introduce new technologies, (3) being the first firm to develop innovative management systems, (4) changing the organizational structure to promote innovation, and (5) entering new foreign markets. Cronbach's alpha is 0.73 .

Control Variables. We included several control variables to account for other explanations of boards' strategic involvement and our Norwegian context. At the firm level, we first control for industry characteristics using a dummy variable with the value of " 1 " if the firm operates within a high-tech sector (Carpenter, Pollock and Leary, 2003). Second, we control for firm size measured as the logarithmic transformation of firm sales in million Norwegian kroner (Machold et al., 2011). At the board-level, we control for board size (measured by the total number of directors serving on the board), the insider-outsider ratio (calculated as the percentage of executive directors on the board), directors' ownership and chairperson's ownership (Sundaramurthy, Pukthuanthong and Kor, 2014). Ownership is measured as the ratio of directors' (chairperson's) shareholding to total shareholding (Zahra, Neubaum and Huse, 2000). With respect to CEO characteristics, we control for CEO ownership (Zahra, Neubaum and Huse, 2000), measured by the ratio of CEO's shareholding to total shareholding. We further control for CEO duality, referring to the situation where the CEO is also the board chair 
(1 for presence, 0 for absence) (Khanna, Jones and Boivie, 2014). Finally, due to the Norwegian setting, we control for the number of employee-elected directors (Zattoni, Gnan and Huse, 2015).

\section{Analyses and Results}

\section{Estimation Methods and Descriptive Statistics}

We applied structural equation modelling (SEM) to test our hypotheses, because it allows simultaneous estimation of multiple relationships between latent constructs. We switch to the Baron-Kenny mediation procedure to test for complementarities among the learning processes (Baron and Kenny, 1986), because SEM tends to produce confounding results for multilateral effects (Whittington et al., 1999). Table 1 shows means, maximum and minimum values, and standard deviations, while Table 2 presents the correlation coefficients for all variables. As expected, directors' knowledge and the learning processes are positively related to boards' strategic involvement. We checked for multicollinearity by calculating variance inflation factors (VIF). The highest VIF (=1.7) appeared when we test for the meditation of all learning processes and was within an acceptable range.

Insert Table 1 about here

Insert Table 2 about here

\section{Structural Equation Modelling Results}

For the SEM analyses, we followed the well-established two-stage procedure (Anderson and Gerbing, 1988). We used confirmatory factor analysis (CFA) to assess the measurement model validity and construct discriminant validity. The measurement model results indicate an acceptable model fit $\left(\mathrm{Chi}^{2}[395]=3.949 ; \mathrm{CFI}=.763\right.$; RMSEA=.078). We further assessed con- 
struct discriminant validity using the composite reliability scores of the multi-item constructs (see table 3). Factor loadings ranged between .37 and $.82(\mathrm{p}<.01)$ and the reliability scores did not fall below 0.71 , indicating acceptable reliability.

Insert Table 3 about here

We used a structural model to test our hypothesized model $\left(\mathrm{Chi}^{2}[54]=5.799 ; \mathrm{CFI}=.846\right.$; RMSEA=.099). To balance SEM parsimony and fit, we ran our analysis excluding the control variables. Our results yet also hold for a variety of other specifications (removing only uncorrelated control variables, z-standardization of variables, logarithmic transformation of variables). Figure 2 presents the results with path coefficients.

Insert Figure 2 about here

Hypothesis 1 predicts that directors' knowledge positively relates to boards' strategic involvement. The path coefficient $(.429 ; \mathrm{p}<.001)$ supports this prediction. Hypothesis 2 a suggests that exploratory learning strengthens the relationship between directors' knowledge and boards' strategic involvement. The path coefficients support this suggestion. Directors' knowledge serves as a positive predictor of exploratory learning $(.563 ; \mathrm{p}<.001)$, and exploratory learning is positively related to boards' strategic involvement (.264; $\mathrm{p}<.001)$. Hypothesis $2 \mathrm{~b}$ suggests that transformative learning strengthens the relationship between directors' knowledge and boards' strategic involvement. The path coefficients lend support for this prediction (directors' knowledge $\rightarrow$ transformative learning: .573; $\mathrm{p}<.001$; transformative learning $\rightarrow$ boards' strategic involvement: .276; p<.001). Hypothesis $2 \mathrm{c}$ predicts that exploitative learning strengthens the relationship between directors' knowledge and boards' strategic involvement. While directors' knowledge and exploitative learning are positively related (.215; 
$\mathrm{p}<.001$ ), the path coefficient between exploitative learning and boards' strategic involvement is only significant at the five percent level $(.119 ; \mathrm{p}<0.05)$. This provides partial support for hypothesis $2 \mathrm{c}$.

\section{Mediation Analysis}

We also test for mediation effects using the Baron-Kenny procedure. Baron and Kenny (1986) suggested that mediation effects are supported if four conditions are met: (1) the independent variable (i.e., directors' knowledge and skills) is significantly related to the mediators (i.e., exploratory learning, transformative learning, exploitative learning) (model 1-3, table 4); (2) the independent variable is significantly related to the dependent variable (i.e., boards' strategic involvement) (model 4, table 4); and, when studied simultaneously, (3) the mediators are significantly related to the dependent variable (model 5-7, table 4); while (4) the independent variable has at least a weakened relationship to the dependent variable when entering the mediators (model 8, table 4). The following equation summarizes the fourth condition of the Baron-Kenny procedure:

$$
y_{i}=\beta_{1} x_{1}+\beta_{2} m_{1}+\beta_{3} m_{2}+\beta_{4} m_{3}+\varpi_{i t}+e_{i t}
$$

where index $i$ stands for the respective board, $\beta i$ represent the regression coefficients, $\mathrm{x}_{1}$ represents the independent variable "directors' knowledge", $m_{l}$ represents the mediator "explorative learning", $m_{2}$ represents the mediator "transformative learning", $m_{3}$ represent the mediator "exploitative learning", $\varpi_{i t}$ is a vector of the control variables, and $e_{i t}$ includes the error term.

Hypothesis 3 predicts that complementarities between exploratory, transformative and exploitative learning strengthens the relationship between directors' knowledge and boards' strategic involvement. Model 8 in Table 4 supports this suggestion. When entering all learning processes as mediators into the model, the relationship between directors' knowledge and 
boards' strategic involvement is weakened. Including all three mediators simultaneously also adds considerably to the model fit (adjusted $\mathrm{R}^{2}=.454, \mathrm{p}<.001 ; \mathrm{F}$-value $=26.70, \mathrm{p}<.001$ ) and lends support for a partial mediation effect of complementary learning processes.

Insert Table 4 about here

\section{Robustness Checks}

We used a variety of alternative specifications to ensure the robustness of our analyses. First, we applied the Sobel test to confirm the existence of mediation effects (Sobel, 1982). The Sobel test assesses whether the estimate linking the independent variable to the dependent variable drops significantly when entering the mediators. The results in Table 5 support the conclusions from the Baron-Kenny procedure. We find a significant relationship for exploratory and transformative learning $(\mathrm{p}<.001)$, but a weaker one for exploitative learning $(\mathrm{p}=.004)$.

Insert Table 5 about here

Using an alternative operationalization for our dependent variable (Pugliese, Minichilli and Zattoni, 2014), the Baron-Kenny mediation analysis produced comparable results to our original conceptualization (Model 1 in Table 6). When entering all learning processes as mediators into the model, directors' knowledge remains a positive but weak predictor of boards' strategic involvement $(.146 ; \mathrm{p}<.05)$, and all three learning processes significantly contribute to explain the dependent variable (exploratory learning: .324, $\mathrm{p}<.001$; transformative learning: $.263, \mathrm{p}<.001$; exploitative learning: .144, $\mathrm{p}<.001$ ). We also found comparable results to our 
initial findings when using a split-sample design that excluded listed firms (Model 2 in Table $6)$.

\author{
Insert Table 6 about here
}

\title{
Discussion
}

Our findings provide new insights concerning directors' knowledge and the mechanisms by which such knowledge is activated towards involvement in strategic tasks. Prior research on directors' knowledge has drawn on a variety of perspectives such as information processing theory (Khanna, Jones and Boivie, 2014), resource dependence theory (Dalziel, Gentry and Bowerman, 2011), or human capital theory (Kor and Sundaramurthy, 2009) to predict boards' strategic involvement. These studies, however, mostly lack a micro-level explanation of how individual directors' knowledge translates into boards' strategic involvement (Johnson, Schnatterly and Hill, 2013), and we sought to address this theoretical gap by advancing an absorptive capacity perspective. Absorptive capacity and its focus on learning processes is particularly relevant since it allows assessing the concurrent implications of exploratory, transformative and exploitative learning in a strategic decision-making context (Lane, Koka and Pathak, 2006). Our findings indicate that boards' strategic involvement indeed hinges on how directors explore and transform their firm-specific and functional knowledge. We find evidence that the intensity, speed and efforts to gather knowledge from inside and outside the board (exploratory learning) and the quality of cognitive interactions during and beyond board meetings (transformative learning) greatly matter for boards' involvement in strategic matters of the firm. Thus, it appears that directors' knowledge needs to be processed to make a meaningful contribution to boards' strategic involvement. 
However, we find only partial support for the prediction that the application of the acquired knowledge (exploitative learning) has a positive impact on boards' strategic involvement. This may be because boards of directors are rarely involved in exploiting strategic decisions, and our finding may be evidence of important boundary conditions. In line with the literature (Machold and Farquhar, 2013; McNulty and Pettigrew, 1999), boards of directors while an important arena to advice firms' executives on strategic matters- may lack the authority to pursue their strategic interests in the relationship with top managers (Dalziel, Gentry and Bowerman, 2011). It thus appears important that future research not only points to knowledge complementarities between boards of directors and top management teams (Sundaramurthy, Pukthuanthong and Kor, 2014), but also addresses how these groups explore, transform, and exploit their combined knowledge in firms' strategic matters.

Our findings also contribute to the literature on learning processes in boards. While prior theorizing (Forbes and Milliken, 1999) and recent evidence (Machold et al., 2011; Zattoni, Gnan and Huse, 2015) have greatly advanced our understanding of whether and how boards can contribute to firms' strategic matters, a recent review of the literature argued that dynamic perspectives may be particularly suited to address the hitherto under-researched link between board processes and directors' cognitive capacities (Pugliese et al., 2009). Subsequent theorizing emphasized that strategic decisions benefit from directors' learning in contexts other than the focal firm (Heyden et al., 2015; McDonald, Westphal and Graebner, 2008; Tuschke, Sanders and Hernandez, 2014). Our findings extend this perspective by highlighting that learning processes are intertwined and have a mutually reinforcing effect on boards' strategic involvement. Scholars could further investigate the conditions for complementarities between learning processes in the board in order to better understand when the combination of all learning aspects is more effective than the sum of its parts (Milgrom and Roberts, 1995). 
Finally, we also make a contribution to the absorptive capacity literature. The majority of research focuses on intra-firm and inter-firm antecedents of absorptive capacity (Flatten, Greve and Brettel, 2011), but rarely considers the process of how potential absorptive capacity (i.e. directors' knowledge) becomes used in a firm governance context. Following a recent call in the literature (Volberda, Foss and Lyles, 2010), we put forward a more actor-centric interpretation of the absorptive capacity concept and focus on its implications at a grouplevel, i.e. boards of directors. Our findings indicate that the concurrent processes of exploratory learning, transformative learning, and exploitative learning in the board help to explain why boards of directors become more (or less) involved in strategic decision-making. Thus, we add an important theoretical layer to the absorptive capacity discussion, highlighting the concept's richness and multidimensionality to explore how potential translates into realized absorptive capacity.

\section{Contributions to Board Practice}

Our theoretical perspective and findings are also highly relevant for practitioners. In particular, the distinction between three different, but inter-related learning processes could serve as a guideline for boards of directors that seek to improve their involvement in strategic matters. As boards are increasingly seeking to strengthen their involvement in strategy, they should place great emphasis on recognizing and understanding external knowledge (exploratory learning) and maintaining and developing knowledge over time (transformative learning), but remain more cautious in directly applying their acquired knowledge (exploitative learning). Taking account of these different effects from learning processes, boards may be better suited to adapt to different strategic decision-making situations.

Our findings further suggest that boards cannot simply assume that selecting knowledgeable directors would result in higher strategic involvement. Directors' knowledge is most 
beneficial when individual knowledge is translated through learning processes to fellow directors. As such, our results highlight the importance of periodic board evaluations to assess whether individual directors are willing to share, obtain, and apply their knowledge. Such evaluations may not only help boards in assessing their current strengths and weaknesses, but also facilitate adaptions to opportunities or threats. 


\section{Opportunities for Future Research}

Several opportunities arise for future research from our study. First, research may benefit from testing the implications of our group-level perspective for firm-level outcomes such as innovation (Ebersberger and Herstad, 2011). The literature offers several methodologies in this regard (Flatten et al., 2011), in particular by combining survey and archival data. Scholars may thereby also continue to assess the validity of our group-level measures of boards' absorptive capacity.

Second, we focused on directors' functional and firm-specific knowledge as antecedents for learning processes (Forbes and Milliken, 1999; Minichilli et al., 2012). While this is consistent with prior absorptive capacity research (Gebauer, Worch and Truffer, 2012), Volberda, Foss and Lyles (2010) argued that little is known how firms are able to store and retrieve knowledge "stocks". As boards are subject to constant change, storing and transmitting directors' knowledge over time becomes particularly important. Thus, we encourage scholars to apply a long-term perspective to study learning processes in boards.

Third, our finding that exploitative learning only partially mediates the directors' knowledge-boards' strategic involvement relationship deserves further attention. We suggest that scholars could account for learning complementarities between boards and top executives. As several studies indicate (Sundaramurthy, Pukthuanthong and Kor, 2014; Westphal, 1999), strategic decisions are typically reflective of inputs from boards and top executives, and research could investigate processual dynamics as well as boundary conditions between the board and the top management team (Walther, Morner and Calabrò, 2017). As our Norwegian context exhibits both similarities and differences in comparison to other countries (Machold et al., 2011), this could include testing our framework in different governance settings where boards follow a unitary structure and face less involved shareholders. 


\section{Summary of Findings and Contributions}

By introducing the concept of absorptive capacity into research on boards, we develop a conceptual model that addresses how learning processes in the board facilitate the deployment of directors' knowledge for strategic decision-making. Our findings indicate that exploratory and transformative learning help to explain how director's knowledge leads to higher levels of strategic involvement, while we only find partial support for this relationship in the case of exploitative learning. Our study further suggests that these three learning processes mutually reinforce each other and have complementary effects. We contribute to an improved theoretical understanding of how directors' knowledge translates into boards' strategic involvement by emphasizing the value of learning processes and provide a deeper understanding of how potential translates into realized absorptive capacity. 
Tables and Figures

\section{Table 1 Descriptive Statistics}

\begin{tabular}{lccccc}
\hline Construct & $\mathbf{N}$ & Min & Max & Mean & SD \\
\hline $\begin{array}{l}\text { Boards' strate- } \\
\text { gic involvement }\end{array}$ & 478 & 1.00 & 5.00 & 3.37 & 0.70 \\
$\begin{array}{l}\text { Directors' } \\
\text { knowledge }\end{array}$ & 484 & 1.67 & 5.00 & 3.83 & 0.60 \\
$\begin{array}{l}\text { Exploratory } \\
\text { learning }\end{array}$ & 484 & 1.00 & 5.00 & 3.22 & 0.67 \\
$\begin{array}{l}\text { Transformative } \\
\text { learning }\end{array}$ & 480 & 1.29 & 5.00 & 3.92 & 0.69 \\
$\begin{array}{l}\text { Exploitative } \\
\text { learning }\end{array}$ & 422 & 1.00 & 5.00 & 2.87 & 0.90 \\
$\begin{array}{l}\text { High-tech firm } \\
\text { Firm size (ln) }\end{array}$ & 481 & 0 & 1 & 0.29 & 0.45 \\
$\begin{array}{l}\text { Board size } \\
\text { Insider-outsider }\end{array}$ & 478 & 0 & 10.65 & 4.10 & 1.79 \\
ratio & 482 & 1 & 12 & 5.20 & 2.10 \\
$\begin{array}{l}\text { Directors' } \\
\text { ownership }\end{array}$ & 482 & 0 & 1 & 0.31 & 0.27 \\
$\begin{array}{l}\text { Chairpersons' } \\
\text { ownership }\end{array}$ & 482 & 0 & 100 & 17.42 & 26.31 \\
CEO ownership & 482 & 0 & 100 & 16.81 & 29.22 \\
$\begin{array}{l}\text { CEO duality } \\
\begin{array}{l}\text { Employee } \\
\text { directors }\end{array}\end{array}$ & 484 & 0 & 100 & 27.54 & 36.96 \\
\hline
\end{tabular}




\section{Table 2 Correlation Matrix}

\begin{tabular}{|c|c|c|c|c|c|c|c|c|c|c|c|c|c|c|c|}
\hline$\#$ & Construct & 1 & 2 & 3 & 4 & 5 & 6 & 7 & 8 & 9 & 10 & 11 & 12 & 13 & 14 \\
\hline 1 & Boards' strategic involvement & 1 & & & & & & & & & & & & & \\
\hline 2 & Directors' knowledge & $.49 * *$ & 1 & & & & & & & & & & & & \\
\hline 3 & Exploratory learning & $.53 * *$ & $.44 * *$ & 1 & & & & & & & & & & & \\
\hline 4 & Transformative learning & $.53 * *$ & $.52 * *$ & $.56^{* *}$ & 1 & & & & & & & & & & \\
\hline 5 & Exploitative learning & $.27 * *$ & $.19 * *$ & $.26 * *$ & $.18 * *$ & 1 & & & & & & & & & \\
\hline 6 & High-tech firm & -.01 & .05 & .09 & .06 & $.14 * *$ & 1 & & & & & & & & \\
\hline 7 & Firm size $(\ln )$ & -.03 & $-.12 * *$ & .02 & -.01 & $.28 * *$ & $.15^{* *}$ & 1 & & & & & & & \\
\hline 8 & Board size & $-.20 * *$ & $-.24 * *$ & -.08 & $-.16 * *$ & $.11^{*}$ & $.09 *$ & $.52 * *$ & 1 & & & & & & \\
\hline 9 & Insider-outsider ratio & .05 & $.17 * *$ & $.10^{*}$ & .04 & -.06 & -.00 & .04 & $-.12 * *$ & 1 & & & & & \\
\hline 10 & Directors' ownership & .00 & -.02 & .02 & -.04 & -.01 & -.09 & $-.15 * *$ & $-.13 * *$ & -.06 & 1 & & & & \\
\hline 11 & Chairpersons' ownership & $.14 * *$ & $.17 * *$ & $.09 * *$ & $.12 *$ & -.03 & -.08 & $-.15 * *$ & $-.35 * *$ & $.12 *$ & -.09 & 1 & & & \\
\hline 12 & CEO ownership & $.20 * *$ & $.33 * *$ & .06 & $.16^{* *}$ & -.02 & -.03 & $-.22 * *$ & $-.44 * *$ & $.32 * *$ & -.03 & .03 & 1 & & \\
\hline 13 & CEO duality & $.12 * *$ & $.19 * *$ & .07 & .07 & -.09 & -.08 & $-.20 * *$ & $-.28 * *$ & $.15^{* *}$ & .08 & $.22 * *$ & $.29 * *$ & 1 & \\
\hline 14 & Employee directors & $-.02 * *$ & $-.14 * *$ & .00 & $-.11 * *$ & .09 & $.14 * *$ & $.53 * *$ & $.66^{* *}$ & $.24 * *$ & $-.21 * *$ & $-.23 * *$ & $-.30 * *$ & $-.18 * *$ & 1 \\
\hline
\end{tabular}

Note: $\quad$ Two-way correlations; significance levels: $* \mathrm{p}<0.05, * * \mathrm{p}<0.01$. 


\section{Table 3 Summary of Main Constructs and Measures}

\begin{tabular}{|c|c|c|c|}
\hline Construct & Measures & $\begin{array}{c}\text { Factor } \\
\text { Loadings }\end{array}$ & $\begin{array}{c}\text { Factor } \\
\text { Reliability }\end{array}$ \\
\hline \multicolumn{4}{|c|}{ Dependent variable } \\
\hline $\begin{array}{c}\text { Boards' } \\
\text { strategic } \\
\text { involve- } \\
\text { ment }\end{array}$ & $\begin{array}{l}\text { The extent to which the board: } \\
\text { - provides advice on general management issues } \\
\text { - provides advice on financial issues } \\
\text { - provides advice on technical issues } \\
\text { - provides advice on market issues } \\
\text { - actively initiates strategy proposals } \\
\text { - makes decisions on long-term strategy }\end{array}$ & $\begin{array}{l}0.636 \\
0.628 \\
0.499 \\
0.679 \\
0.420 \\
0.480\end{array}$ & 0.851 \\
\hline \multicolumn{4}{|c|}{ Independent variable } \\
\hline $\begin{array}{l}\text { Directors' } \\
\text { knowledge }\end{array}$ & $\begin{array}{l}\text { The extent to which board members have knowledge of: } \\
\text { - firm's main operations } \\
\text { - firm's critical technology and key competence } \\
\text { - firm's weak sides concerning products and services } \\
\text { - the development of the firm's technology } \\
\text { - firm's health, safety, and environment } \\
\text { - developments concerning firm's markets and customer's needs }\end{array}$ & $\begin{array}{l}0.704 \\
0.787 \\
0.701 \\
0.722 \\
0.557 \\
0.567\end{array}$ & 0.834 \\
\hline \multicolumn{4}{|c|}{ Mediating variables } \\
\hline $\begin{array}{c}\text { Explora- } \\
\text { tory } \\
\text { learning }\end{array}$ & $\begin{array}{l}\text { The extent to which board members: } \\
\text { - have a fast information flow between themselves } \\
\text { - explore information before meetings } \\
\text { - actively seek information in addition to management reports } \\
\text { - are familiar with employees' view on health, safety, and envi- } \\
\text { ronment } \\
\text { - are familiar with employees' view on management-union col- } \\
\text { laborations } \\
\text { - are building networks } \\
\text { - are lobbying and legitimating }\end{array}$ & $\begin{array}{l}0.582 \\
0.475 \\
0.442 \\
0.737 \\
0.501 \\
0.369 \\
0.461\end{array}$ & 0.714 \\
\hline $\begin{array}{c}\text { Transfor- } \\
\text { mative } \\
\text { learning }\end{array}$ & $\begin{array}{l}\text { The extent to which board members: } \\
\text { - } \text { are familiar with each other's competence } \\
\text { - } \text { have a good match of work, knowledge and skills } \\
\text { - fully use their knowledge and skill } \\
\text { - give sufficient priority to the board tasks } \\
\text { - } \text { are available if needed } \\
\text { - } \text { are all active during their meetings }\end{array}$ & $\begin{array}{l}0.797 \\
0.816 \\
0.662 \\
0.691 \\
0.574 \\
0.585\end{array}$ & 0.845 \\
\hline $\begin{array}{c}\text { Exploi- } \\
\text { tative } \\
\text { learning }\end{array}$ & $\begin{array}{l}\text { The extent to which the firm can be considered as: } \\
\text { - being the first firm to introduce new products to the market } \\
\text { - being the first firm to develop and introduce new technologies } \\
\text { - being the first firm to develop innovative management systems } \\
\text { - changing the organizational structure to promote innovation } \\
\text { - entering new foreign markets }\end{array}$ & $\begin{array}{l}0.631 \\
0.659 \\
0.583 \\
0.615 \\
0.464\end{array}$ & 0.729 \\
\hline
\end{tabular}


Table 4 Results of Baron-Kenny Mediation Analysis

\begin{tabular}{|c|c|c|c|c|c|c|c|c|}
\hline Variables & $\begin{array}{r}\text { Model 1 } \\
\text { Exploratory } \\
\text { learning }\end{array}$ & $\begin{array}{l}\text { Model } 2 \\
\text { Transforma- } \\
\text { tive learning }\end{array}$ & $\begin{array}{r}\text { Model } 3 \\
\text { Exploitative } \\
\text { learning }\end{array}$ & $\begin{array}{r}\text { Model } 4 \\
\text { Boards' } \\
\text { strategic } \\
\text { involvement }\end{array}$ & $\begin{array}{r}\text { Model 5 } \\
\text { Boards } \\
\text { strategic } \\
\text { involvement }\end{array}$ & $\begin{array}{r}\text { Model 6 } \\
\text { Boards } \\
\text { strategic } \\
\text { involvement }\end{array}$ & $\begin{array}{r}\text { Model 7 } \\
\text { Boards } \\
\text { strategic } \\
\text { involvement }\end{array}$ & $\begin{array}{r}\text { Model 8 } \\
\text { Boards' } \\
\text { strategic } \\
\text { involvement }\end{array}$ \\
\hline Directors' knowledge & $0.473 * * *$ & $0.534 * * *$ & $0.234 * * *$ & $0.472 * * *$ & $0.287 * * *$ & $0.269 * * *$ & $0.453 * * *$ & $0.203 * * *$ \\
\hline Exploratory learning & & & & & $0.391 * * *$ & & & $0.265 * * *$ \\
\hline Transformative learning & & & & & & $0.376^{* * *}$ & & $0.268 * * *$ \\
\hline Exploitative learning & & & & & & & $0.175 * * *$ & $0.106^{* *}$ \\
\hline High-tech firm & 0.059 & 0.012 & 0.081 & -0.033 & -0.054 & -0.039 & -0.053 & -0.062 \\
\hline Firm size (ln) & 0.080 & $0.130 * *$ & $0.308 * * *$ & $0.164 * *$ & $0.131 * *$ & $0.119 *$ & 0.095 & 0.049 \\
\hline Board size & -0.061 & -0.078 & -0.001 & -0.050 & -0.026 & -0.016 & -0.044 & 0.001 \\
\hline Insider-outsider ratio & 0.027 & -0.074 & -0.066 & -0.056 & -0.069 & -0.032 & -0.054 & -0.049 \\
\hline Directors' ownership & 0.044 & -0.041 & 0.034 & 0.024 & 0.006 & 0.040 & 0.004 & 0.016 \\
\hline Chairpersons' ownership & 0.033 & 0.041 & -0.005 & 0.040 & 0.025 & 0.036 & 0.024 & 0.030 \\
\hline CEO ownership & -0.090 & 0.023 & 0.006 & 0.080 & $0.117 *$ & 0.076 & 0.076 & $0.101 *$ \\
\hline CEO duality & 0.011 & -0.018 & -0.072 & -0.014 & -0.016 & -0.003 & 0.016 & 0.016 \\
\hline Employee directors & 0.035 & -0.044 & -0.034 & $-0.123^{\dagger}$ & $-0.133 *$ & -0.105 & -0.094 & -0.091 \\
\hline $\mathrm{R}^{2}$ & 0.231 & 0.315 & 0.148 & 0.285 & 0.403 & 0.384 & 0.327 & 0.472 \\
\hline Adjusted $\mathrm{R}^{2}$ & 0.214 & 0.299 & 0.126 & 0.269 & 0.389 & 0.369 & 0.308 & 0.454 \\
\hline F-value & $13.53 * * *$ & $20.51 * * *$ & $6.81 * * *$ & $17.82 * * *$ & $27.35 * * *$ & $25.13 * * *$ & $17.28 * * *$ & $26.70 * * *$ \\
\hline
\end{tabular}


Table 5 Results of Sobel's Test

\begin{tabular}{|c|c|c|c|c|}
\hline $\begin{array}{l}\text { Independent } \\
\text { Variable }\end{array}$ & $\begin{array}{l}\text { Mediator } \\
\text { Variable }\end{array}$ & $\begin{array}{l}\text { Dependent } \\
\text { variable }\end{array}$ & $\begin{array}{l}\text { Sobel test } \\
\text { statistic }\end{array}$ & $\mathbf{p}$ \\
\hline $\begin{array}{l}\text { Directors' } \\
\text { knowledge }\end{array}$ & $\begin{array}{l}\text { Exploratory } \\
\text { Learning }\end{array}$ & $\begin{array}{l}\text { Boards' } \\
\text { strategic } \\
\text { involvement }\end{array}$ & .201 & .000 \\
\hline $\begin{array}{l}\text { Directors' } \\
\text { knowledge }\end{array}$ & $\begin{array}{l}\text { Transformative } \\
\text { learning }\end{array}$ & $\begin{array}{l}\text { Boards' } \\
\text { strategic } \\
\text { involvement }\end{array}$ & .237 & .000 \\
\hline $\begin{array}{l}\text { Directors' } \\
\text { knowledge }\end{array}$ & $\begin{array}{l}\text { Exploitative } \\
\text { Learning }\end{array}$ & $\begin{array}{l}\text { Boards' } \\
\text { strategic } \\
\text { involvement }\end{array}$ & .040 & .004 \\
\hline
\end{tabular}

Note: Significance levels: ${ }^{\dagger}<.0 .10, * \mathrm{p}<0.05, * * \mathrm{p}<0.01, * * * \mathrm{p}<0.001$. 
Table 6 Results of Robustness Checks

\begin{tabular}{|c|c|c|}
\hline Variables & $\begin{array}{r}\text { Model 1 } \\
\text { Boards' strategic } \\
\text { involvement }\end{array}$ & $\begin{array}{r}\text { Model } 2 \\
\text { Boards' strategic } \\
\text { involvement }\end{array}$ \\
\hline Directors' knowledge & $0.146^{* *}$ & $0.215^{* * *}$ \\
\hline Exploratory learning & $0.324 * * *$ & $0.265 * * *$ \\
\hline Transformative learning & $0.263 * * *$ & $0.279 * * *$ \\
\hline Exploitative learning & $0.144 * * *$ & $0.097 *$ \\
\hline High-tech firm & -0.036 & $-0.080^{*}$ \\
\hline Firm size (ln) & -0.012 & 0.032 \\
\hline Board size & 0.019 & -0.019 \\
\hline Insider-outsider ratio & -0.008 & -0.049 \\
\hline Directors' ownership & -0.063 & 0.019 \\
\hline Chairpersons' ownership & -0.026 & 0.018 \\
\hline CEO ownership & $0.001 *$ & $0.096^{*}$ \\
\hline CEO duality & 0.046 & 0.017 \\
\hline Employee directors & -0.024 & -0.080 \\
\hline $\mathrm{R}^{2}$ & 0.465 & 0.491 \\
\hline Adjusted $\mathrm{R}^{2}$ & 0.447 & 0.471 \\
\hline F-value & $25.98 * * *$ & $25.57 * * *$ \\
\hline
\end{tabular}

Note: $\quad$ Significance levels: ${ }^{\dagger}<.0 .10, * \mathrm{p}<0.05, * * \mathrm{p}<0.01, * * * \mathrm{p}<0.001$.

Model 1 conceptualizes the dependent variable following the operationalization by Pugliese, Minichilli and Zattoni (2014). Model 2 excludes all listed firms. 
Figure 1 A Conceptual Framework of Absorptive Capacity in Boards of Directors

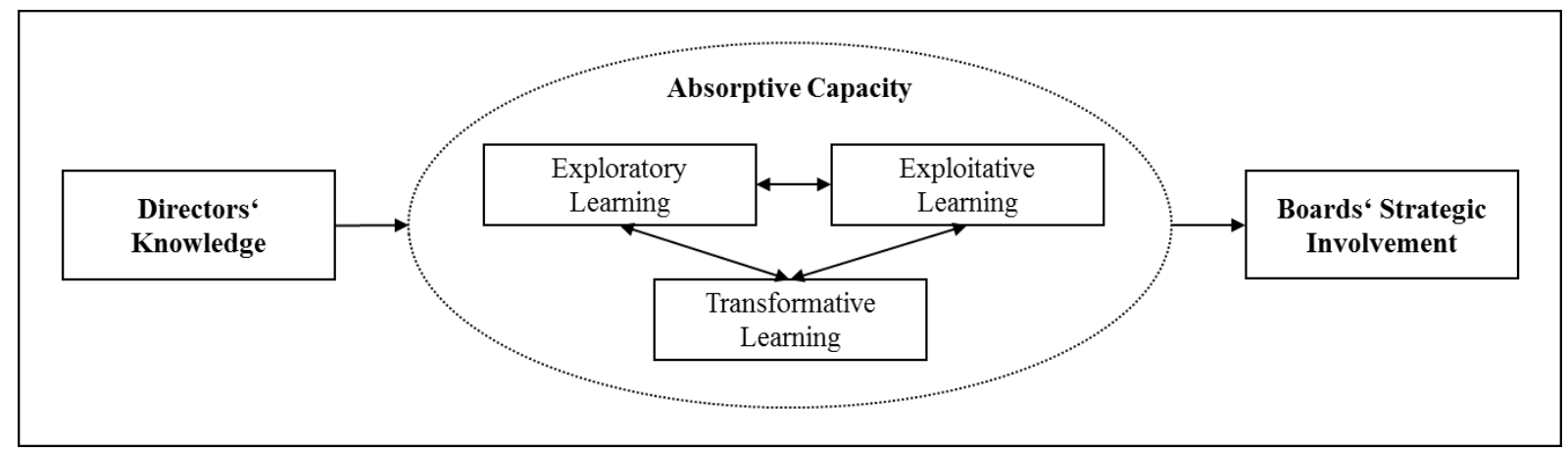


Figure 2 Results for the Model of Absorptive Capacity in Boards of Directors

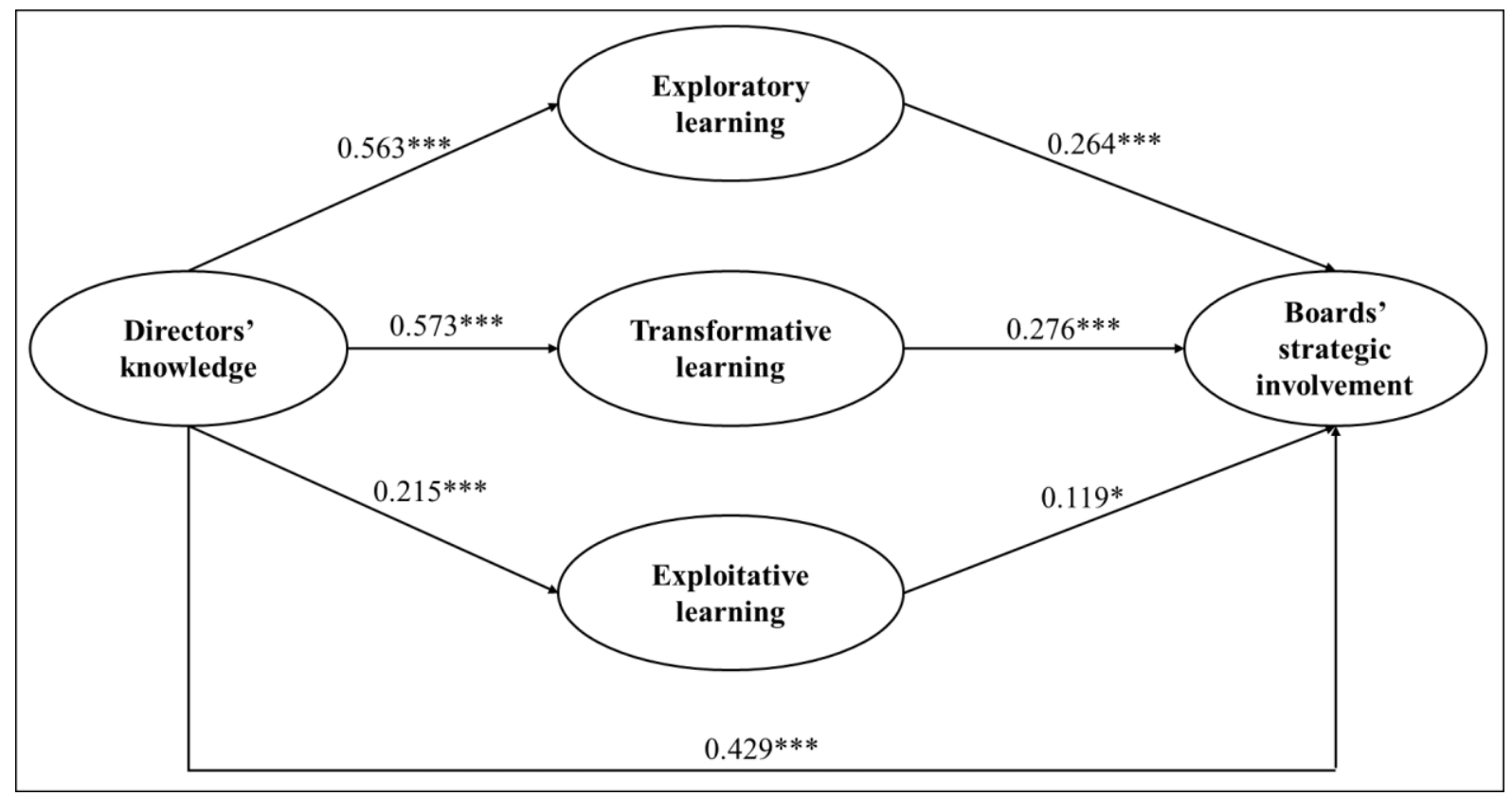

Note: $\quad$ H3 was tested using multiple linear regression analysis (see Table 4).

Significance levels: $* \mathrm{p}<0.05, * * \mathrm{p}<0.01, * * * \mathrm{p}<0.001$. 


\section{References}

Anderson, J. C. and D. W. Gerbing, 1988, "Structural equation modeling in practice: A review and recommended two-step approach". Psychological Bulletin, 103: 411-423.

Argote. L., B. McEvily and R. Reagans, 2003, "Managing knowledge in organizations: An integrative framework and review of emerging themes". Organization Science, 49: 571582.

Argote, L. and E. Miron-Spektor, 2011, "Organizational learning: From experience to knowledge". Organization Science, 22: 1123-1137.

Bankewitz, M., 2017, "Board advisory tasks: The importance to differentiate between functional and firm-specific advice". European Management Review, online first, doi: 10.1111/emre.12139.

Baron, R. M. and D. A. Kenny, 1986, "The moderator-mediator variable distinction in social psychological research: Conceptual, strategic, and statistical considerations". Journal of Personality and Social Psychology, 51: 1173.

Cadiz, D., J. E. Sawyer and T. L. Griffith, 2009, "Developing and validating field measurement scales for absorptive capacity and experienced community of practice". Educational and Psychological Measurement, 69: 1035-1058.

Camisón, C. and B. Forés, 2010, "Knowledge absorptive capacity: New insights for its conceptualization and measurement". Journal of Business Research, 63: 707-715.

Carpenter, M. A., T. G. Pollock and M. M. Leary, 2003, "Testing a model of reasoned risktaking: Governance, the experience of principals and agents, and global strategy in hightechnology IPO firms". Strategic Management Journal, 24: 803-820.

Carpenter, M. A. and J. D. Westphal, 2001, "The strategic context of external network ties: Examining the impact of director appointments on board involvement in strategic decision making". Academy of Management Journal, 44: 639-660.

Cohen, W. M. and D. A. Levinthal, 1990, "Absorptive capacity: A new perspective on learning and innovation". Administrative Science Quarterly, 35: 128-152.

Daily, C. M., D. R. Dalton and A. A. Cannella, 2003, "Corporate governance: Decades of dialogue and data". Academy of Management Review, 28: 371-382.

Dalziel, T., R. J. Gentry and M. Bowerman, 2011, "An integrated agency-resource dependence view of the influence of directors' human and relational capital on firms' R\&D spending". Journal of Management Studies, 48: 1217-1242.

De Maere, J., A. Jorissen and L. M. Uhlaner, 2014, "Board capital and the downward spiral: Antecedents of bankruptcy in a sample of unlisted firms". Corporate Governance: An International Review, 22: 387-407.

Ebersberger, B. and S. J. Herstad, 2011, "Product innovation and the complementarities of external interfaces". European Management Review, 8: 117-135. 
Ellison, G. and D. Fudenberg, 1995, "Word-of-mouth communication and social learning". Quarterly Journal of Economics, 110: 93-125.

Farquhar, S. 2011, "The impact of board processes on board role performance and effectiveness: An empirical study of UK listed companies". PhD Thesis: University of Wolverhampton.

Flatten, T. C., A. Engelen, S. A. Zahra and M. Brettel, 2011, "A measure of absorptive capacity: Scale development and validation". European Management Journal, 29: 98-116.

Flatten, T. C., G. I. Greve and M. Brettel, 2011, "Absorptive capacity and firm performance in SMEs: The mediating influence of strategic alliances". European Management Review, 8: 137-152.

Forbes, D. P. and F. J. Milliken, 1999, "Cognition and corporate governance: Understanding boards of directors as strategic decision-making groups". Academy of Management Review, 24: 489-505.

Gebauer, H., H. Worch and B. Truffer, 2012, "Absorptive capacity, learning processes and combinative capabilities as determinants of strategic innovation". European Management Journal, 30: 57-73.

Grosvold, J., S. Brammer and B. Rayton, 2007, "Board diversity in the United Kingdom and Norway: an exploratory analysis”. Business Ethics: A European Review, 16: 344-357.

Hambrick, D. C. and P. A. Mason, 1984, "Upper echelons: The organization as a reflection of its top managers". Academy of Management Review, 9: 193-206.

Heyden, M. L. M., J. Oehmichen, S. Nichting and H. W. Volberda, 2015, "Board background heterogeneity and exploration-exploitation: The role of the institutionally adopted board model". Global Strategy Journal, 5: 154-176.

Huse, M., 2007, Boards, Governance and Value Creation: The Human Side of Corporate Governance. Cambridge, UK: Cambridge University Press.

Huse, M., 2009, "The 'value creating board' surveys: A benchmark" in M. Huse, 2009, The value creating board: Corporate governance and organizational behaviour, London, UK: Routledge, pp. 367-383.

Huse, M., S. T. Nielsen and I. M. Hagen, 2009, "Women and employee-elected board members, and their contributions to board control tasks". Journal of Business Ethics, 89: 581-597.

Inglis, S. and L. Weaver, 2000, "Designing agendas to reflect board roles and responsibilities: Results of a study". Nonprofit Management and Leadership, 11: 65-77.

Jansen, J. J. P., F. A. J. Van Den Bosch and H. W. Volberda, 2005, "Managing potential and realized absorptive capacity: How do organizational antecedents matter?". Academy of Management Journal, 48: 999-1015.

Johnson, S. G., K. Schnatterly and A. D. Hill, 2013, "Board composition beyond independence: Social capital, human capital, and demographics". Journal of Management, 39: 232-262. 
Judge, W. Q. and G. H. Dobbins, 1995, "Antecedents and effects of outside director's awareness of CEO decision style". Journal of Management, 21: 43-64.

Judge, W. Q., M. A. Witt, A. Zattoni, T. Talaulicar, J. J. Chen, K. Lewellyn, H. W. Hu, D. Shukla, J. Gabrielsson and F. Lopez, 2015, "Corporate governance and IPO underpricing in a cross-national sample: A multilevel knowledge-based view". Strategic Management Journal, 36: 1174-1185.

Katila, R. and G. Ahuja, 2002, "Something old, something new: A longitudional study of search behavior and new product introduction". Academy of Management Journal, 45: 1183-1194.

Khanna, T., R. Gulati and N. Nohria, 1998, "The dynamics of learning alliances: Competition, cooperation, and relative scope". Strategic Management Journal, 19: 193-210.

Khanna, P., C. D. Jones and S. Boivie, 2014, "Director human capital, information processing demands, and board effectiveness". Journal of Management, 40: 557-585.

Kor, Y. Y. and C. Sundaramurthy, 2009, "Experience-based human capital and social capital of outside directors". Journal of Management, 35: 981-1006.

Lane, P. J., B. R. Koka and S. Pathak, 2006, "The reification of absorptive capacity: A critical review and rejuvenation of the construct". Academy of Management Review, 31: 833-863.

Lane, P. and M. Lubatkin, 1998, "Relative absorptive capacity and interorganizational learning". Strategic Management Journal 19: 461-477.

Lindell, M. K. and D. J. Whitney, 2001, "Accounting for common method variance in crosssectional research designs". Journal of Applied Psychology, 86: 114-121.

Lohe, F.-W. and A. Calabrò, 2017, "Please do not disturb! Differentiating board tasks in family and non-family firms during financial distress". Scandinavian Journal of Management, 33: 36-49.

Machold, S. and S. Farquhar, 2013, "Board task evolution: A longitudinal field study in the UK". Corporate Governance: An International Review, 21: 147-164.

Machold, S., M. Huse, A. Minichilli and M. Nordqvist, 2011, "Board leadership and strategy involvement in small firms: A team production approach". Corporate Governance: An International Review, 19: 368-383.

Martinkenaite, I. and K. J. Breunig, 2016, "The emergence of absorptive capacity through micro-macro level interactions". Journal of Business Research, 69: 700-708.

Massey, G. R. and P. L. Dawes, 2007, "The antecedents and consequence of functional and dysfunctional conflict between marketing managers and sales managers". Industrial Marketing Management, 36: 1118-1129.

McDonald, M. L., J. D. Westphal and M. E. Graebner, 2008, "What do they know? The effects of outside director acquisition experience on firm acquisition performance". Strategic Management Journal, 29: 1155-1177. 
McNulty, T. and A. Pettigrew, 1999, "Strategists on the board". Organization Studies, 20: 4774.

Milgrom, P. and J. Roberts, 1995, "Complementarities and fit strategy, structure, and organizational change in manufacturing". Journal of Accounting and Economics, 19: 179208.

Minichilli, A. and C. Hansen, 2007, "The board advisory tasks in small firms and the event of crises". Journal of Management \& Governance, 11: 5-22.

Minichilli, A., A. Zattoni, S. Nielsen and M. Huse, 2012, "Board task performance: An exploration of micro-and macro-level determinants of board effectiveness". Journal of Organizational Behavior, 33: 193-215.

Mishra, C.S., T. Randoy and J.I. Jenssen, 2001, "The effect of founding family influence on firm value and corporate governance". Journal of International Financial Management and Accounting, 12(3): 235-259.

Nielsen, S. and M. Huse, 2010, "Women directors' contribution to board decision-making and strategic involvement: The role of equality perception". European Management Review, 7: $16-29$.

Parker, L. D., 2007, "Internal governance in the nonprofit boardroom: A participant observer study". Corporate Governance: An International Review, 15: 923-934.

Payne, G. T., G. S. Benson and D. L. Finegold, 2009, "Corporate board attributes, team effectiveness and financial performance". Journal of Management Studies, 46: 704-731.

Pirson, M. and S. Turnbull, 2011, "Corporate governance, risk management, and the financial crisis: An information processing view". Corporate Governance: An International Review, 19: 459-470.

Podsakoff, P. M., S. B. MacKenzie, J.-Y. Lee and N. P. Podsakoff, 2003, "Common method biases in behavioral research: A critical review of the literature and recommended remedies". Journal of Applied Psychology, 88: 879-903.

Post, C. and K. Byron, 2015, "Women on boards and firm financial performance: A metaanalysis". Academy of Management Journal, 58: 1546-1571.

Pugliese, A., P. J. Bezemer, A. Zattoni, M. Huse, F. A. J. Van den Bosch and H. W. Volberda, 2009, "Boards of directors' contribution to strategy: A literature review and research agenda". Corporate Governance: An International Review, 17: 292-306.

Pugliese, A., A. Minichilli and A. Zattoni, 2014, "Integrating agency and resource dependence theory: Firm profitability, industry regulation, and board tasks performance". Journal of Business Research, 67: 1189-1200.

Rasmussen, J. L. and M. Huse, 2011, "Corporate governance in Norway: Women and employee-elected board members" in C. A. Mallin, 2011, Handbook on International Corporate Governance: Country Analyses, Cheltenham, UK: Edward Elgar, pp. 121-148.

Rindova, V. P., 1999, "What corporate boards have to do with strategy: A cognitive perspective". Journal of Management Studies, 36: 953-975. 
Rosenkopf, L. and A. Nerkar, 2001, "Beyond local search: Boundary-spanning, exploration, and impact in the optical disk industry", Strategic Management Journal, 22: 287-306.

Sinani, E., A. Stafsudd, S. Thomsen, C. Edling and T. Randøy, 2008, "Corporate governance in Scandinavia: Comparing networks and formal institutions". European Management Review, 5: 27-40.

Sobel, M. E., 1982, "Asymptotic confidence intervals for indirect effects in structural equation models". Sociological Methodology, 13: 290-312.

Sundaramurthy, C., K. Pukthuanthong and Y. Kor, 2014, "Positive and negative synergies between the CEO's and the corporate board's human and social capital: A study of biotechnology firms". Strategic Management Journal, 35: 845-868.

Szulanski, G., R. Cappetta and R. J. Jensen, 2004, "When and how trustworthiness matters: Knowledge transfer and the moderating effect of causal ambiguity". Organization Science, 15: 600-613.

Terjesen, S., R. Sealy and V. Singh, 2009, "Women directors on corporate boards: A review and research agenda". Corporate Governance: An International Review, 17: 320-337.

Todorova, G. and B. Durisin, 2007, "Absorptive capacity: Valuing a reconceptualization". Academy of Management Review, 32: 774-786.

Torchia, M., A. Calabrò and M. Huse, 2011, "Women directors on corporate boards: From tokenism to critical mass". Journal of Business Ethics, 102: 299-317.

Tortoriello, M., 2015, "The social underpinnings of absorptive capacity: The moderating effects of structural holes on innovation generation based on external knowledge". Strategic Management Journal, 36: 586-597.

Tuschke, A., G. W. M. Sanders and E. Hernandez, 2014, "Whose experience matters in the boardroom? The effects of experiential and vicarious learning on emerging market entry". Strategic Management Journal, 35: 398-418.

van Ees, H., J. Gabrielsson and M. Huse, 2009, "Toward a behavioral theory of boards and corporate governance". Corporate Governance: An International Review, 17: 307-319.

van Ees, H., G. van der Laan and T. J. B. M. Postma, 2008, "Effective board behavior in the Netherlands". European Management Journal, 26: 84-93.

Vandenbroucke, E., M. Knockaert and D. Ucbasaran, 2016, "Outside board human capital and early stage high-tech firm performance". Entrepreneurship Theory and Practice, 40: 759779 .

Volberda, H. W., N. J. Foss and M. A. Lyles, 2010, "Absorbing the concept of absorptive capacity: How to realize its potential in the organization field". Organization Science, 21: 931-951.

Voordeckers, W., A. Van Gils, J. Gabrielsson, D. Politis and M. Huse, 2014, "Board structures and board behaviour: A cross-country comparison of privately held SMEs in Belgium, the Netherlands and Norway". International Journal of Business Governance and Ethics, 9: 197-219. 
Walther, A., Morner, M. and A. Calabrò, 2017, "The role of behaviorally integrated nominating committees in non-executive director selection processes". European Management Journal, 35: 351-361.

Westphal, J. D., 1999, "Collaboration in the boardroom: Behavioral and performance consequences of CEO-board social ties". Academy of Management Journal, 42: 7-24.

Westphal, J. D., M.-D. L. Seidel and K. J. Stewart, 2001, "Second-order imitation: Uncovering latent effects of board network ties". Administrative Science Quarterly, 46: 717-747.

Westphal, J. D. and E. J. Zajac, 2013, "A behavioral theory of corporate governance: Explicating the mechanisms of socially situated and socially constituted agency". The Academy of Management Annals, 7: 607-661.

Whittington, R., A. Pettigrew, S. Peck, E. Fenton and M. Conyon, 1999, "Change and complementarities in the new competitive landscape: A European panel study, 19921996". Organization Science, 10: 583-600.

Zahra, S. A., I. Filatotchev and M. Wright, 2009, "How do threshold firms sustain corporate entrepreneurship? The role of boards and absorptive capacity". Journal of Business Venturing, 24: 248-260.

Zahra, S. A. and G. George, 2002, "Absorptive capacity: A review, reconceptualization, and extension". Academy of Management Review, 27: 185-203.

Zahra, S. A., D. O. Neubaum and M. Huse, 2000, "Entrepreneurship in medium-size companies: exploring the effects of ownership and governance systems". Journal of Management, 26: 947-976.

Zahra, S. A. and J. A. Pearce, 1989, "Boards of directors and corporate financial performance: A review and integrative model". Journal of Management, 15: 291-334.

Zattoni, A., L. Gnan and M. Huse, 2015, "Does family involvement influence firm performance? Exploring the mediating effects of board processes and tasks". Journal of Management, 41: 1214-1243.

Zhang, P., 2010, "Board information and strategic tasks performance". Corporate Governance: An International Review, 18: 473-487.

Zona, F., 2016, "CEO leadership and board decision processes in family-controlled firms: Comparing family and non-family CEOs". Small Business Economics, 47: 735-753. 